\title{
Heliconia acuminata reproductive success is independent of local floral density.
}

\author{
Emilio M. BRUNA ${ }^{1,2}$, W. John KRESS ${ }^{3,2},{ }^{2}$ Francisco MARQUES, Osmaildo Ferreira da SILVA ${ }^{2}$
}

\begin{abstract}
Reproductive plants in tropical forests are patchily distributed, with some in large aggregations of reproductive consepecifics while others are relatively isolated. This variation in floral density is hypothesized to have a major effect on plant reproductive success, since individuals in higher density neighborhoods can attract more or higher quality pollinators. We experimentally tested this hypothesis with populations of the understory herb Heliconia acuminata in central Amazonia. We created replicated plots in which reproductive plant density spanned the range of naturally occurring floral neighborhood size, then measured three surrogates of plant fitness in focal plants in each array. There was no significant difference between any of the three floral neighborhood treatments in total seed production, fruit set, or the number of seeds produced per fruit. Pollinator visitation rates to plants in all treatments were extremely low, with many plants not visited at all during the observation period. This could be because $H$. acuminata's hummingbird pollinators are unable to find the widely scattered reproductive plants, however this hypothesis appears unlikely. Instead, natural flowering plant densities may simply be below the threshold value at which neighborhood effects become important, even in "high-density" aggregations. Nutrient limitation, selective fruit abortion, and reproduction via male rather than female function may also be playing a role. We argue the absence of neighborhood effects may be a general phenomenon in central Amazonian forests, though additional experiments with other plant-pollinator systems are needed to determine the extent to which this hypothesis is supported.
\end{abstract}

\section{KEY WORDS}

Phaethornis, resource limitation, pollinator limitation, transplants

\section{O sucesso reprodutivo de Heliconia acuminata é independente da densidade floral local.}

\begin{abstract}
RESUMO
Plantas reprodutivas em florestas tropicas são distribuidas em manchas, com algumas em grandes agregações coespecíficas e outras relativamente isoladas. A hipótese é que esta variação na densidade de flores em um local tem um grande efeito no sucesso reprodutivo de plantas, já que indivíduos em agregações maiores poderiam atrair mais polinizadores ou polinizadores de melhor qualidade. Esta hipótese foi testada na Amazônia central com populações da erva de sub-bosque Heliconia acuminata. Foram criadas parcelas em que a densidade de plantas reprodutivas simula a densidade natural, e medimos componentes de sucesso reprodutivo em plantas focais em cada parcela. Não houve diferença significativa entre nenhum dos tratamentos de densidade de flores em termos da taxa de produção de frutos, de produção total de sementes por planta, ou de produção de sementes por fruto. Visitas por polinizadores eram extremamente raras, e muitas plantas não receberam nenbuma visita. Isto poderia ser porque os beija-flores que polinizam Heliconia acuminata são muito ineficientes, mas isto parece não ser o caso. A densidade de flores pode simplesmente estar abaixo do limiar em que efeitos de densidade local são importantes, até mesmo em agregações de maior densidade. Limitação de nutrientes, aborto seletivo de frutos, e reprodução via função masculina e não feminina também poderiam ser responsáveis. Sugere-se que a ausência de efeitos de densidade local na reprodução de plantas pode ser um fenômeno geral nas florestas da Amazônia central, embora experimentos adicionais com outros sistemas são necessários para determinar se esta bipótese é valida.
\end{abstract}

\section{PALAVRAS-CHAVE}

Phaethornis, limitacão de nutrientes, limitacão de polinizadores, transplantes

${ }^{1}$ Department of Wildlife Ecology and Conservation University of Florida-PO Box 110430 - Gainesville, FL32611 USA-BrunaE@wec.ufl.edu (Authorfor correspondence)

${ }^{2}$ Biological Dynamics of Forest Fragments Project PDBFF-INPA - CP 478 - Manaus, AM 69011-970 Brazil

${ }^{3}$ Department of Systematic Biology National Museum of Natural History Smithsonian Institution Washington, DC 20560-0166 USA 


\section{ACTA \\ AMAZONICA}

Heliconia acuminata REPRODUCTIVE SUCCESS

IS INDEPENDENT OF LOCAL FLORAL DENSITY

\section{INTRODUCTION}

Plants in tropical forests are patchily distributed, and as a result some individuals will be isolated from conspecifics while others are found in high-density aggregations (Harper, 1977). This is true of reproductive plants as well - while some individuals will be located near flowering conspecifics, others will be relatively isolated from reproductive partners (Kunin, 1997). This variation in the local abundance of flowering plants, also known as a plant's floral neighborhood (Feinsinger et al., 1986), is thought to have a major influence on individual reproductive success (Feinsinger et al., 1991; Kunin, 1993; Agren, 1996). Considerable observational and experimental evidence supports this hypothesis. Plants found in dense floral neighborhoods are often visited by pollinators more frequently, and as result have increased rates of pollen deposition and fruit production (Calvo and Horvitz, 1990; Burd, 1994; Corbet, 1998). In contrast, isolated plants often have low fruit and seed sets, in part because they attract few or low quality visitors (Feinsinger et al., 1986; Jennersten and Nilsson, 1993; Kunin, 1997).

While studies addressing the importance of floral neighborhoods for reproductive success have been conducted in a several Neotropical sites (Montalvo and Ackerman, 1987; Horvitz and Schemske, 1988; Ackerman, 1989), to our knowledge none have been conducted in central Amazonia. Interestingly, limited reproduction resulting from low-density floral neighborhoods may be particularly acute in these forests, which have amongst the lowest recorded levels of plant fertility in the tropics (Gentry and Emmons, 1987). If visits by pollinators to low-density aggregations in these forests are rare, then even minor increases in the local abundance of reproductive plants could translate into substantial increases in individual fitness.

Heliconia acuminata is an understory herb commonly found in the central Amazon (Berry and Kress, 1991). As part of a long-term study of $H$. acuminata population dynamics, a network of permanent $5000 \mathrm{~m}^{2}$ demographic plots has been established in six of the continuous forest reserves administered by the Biological Dynamics of Forest Fragments Project (BDFFP), located $70 \mathrm{~km}$ north of Manaus, Brazil $\left(2^{\circ} 30^{\prime} \mathrm{S}, 60^{\circ} \mathrm{W}\right)$. Each of these plots consists of fifty 10x10 m subplots (see Bruna, 2002; Bruna and Kress, 2002 for details), in which the number of flowering plants ranges from 1-7 (Fig. 1). We evaluated the consequences of variation in floral neighborhood size for $H$. acuminata reproductive success using an experiment in which we manipulate the local density of flowering plants across this range of observed values. Specifically, we test the hypothesis that reproductive success will increase as the local density of flowering conspecifics increases. We hypothesize such increases would be due to increased visitation by pollinators to plants in higher density floral neighborhoods.

\section{MATERIAL AND METHODS}

All fieldwork was conducted in BDFFP Reserve \#1501 $\left(2^{\circ} 30^{\prime} \mathrm{S}, 60^{\circ} \mathrm{W}\right)$, located approximately $70 \mathrm{~km}$ north of Manaus. This 800 ha reserve is embedded in over 10,000 hectares of nonflooded rain forest. The topography is rugged and ranges from $50-150 \mathrm{~m}$ in elevation. Soils are nutrient-poor xanthic ferralsols that drain well (Laurance et al., 1999). Mean annual temperature is $26^{\circ} \mathrm{C}$ (range $19-39^{\circ} \mathrm{C}$ ) and mean annual rainfall ranges from 1900-2300 $\mathrm{mm}$ (BDFFP records). A marked dry season occurs from June-November.

Heliconia acuminata is an understory herb native to the nonflooded forests of Amazonia and the Guyanas. It is a self-incompatible hermaphroditic perennial with limited vegetative reproduction (Bruna and Kress, pers. obs.). Flowering begins in late January and continues through April; during this time it is the most abundant flowering plant in the understory (Bruna and Kress, pers. obs.). Most reproductive plants have one inflorescence with a total of 20-25 flowers. Each flower is open for only one day, after which the perianth and the style abscise. The fruits produce a maximum of three seeds each (Bruna and Kress, 2002), and mature fruits are bird-dispersed (Kress, 1983). In our study sites $H$. acuminata is pollinated by two hummingbird species: the Long-tailed Hermit Phaetbornis superciliosus and the Straight-billed Hermit $P$. bourcieri (Stouffer and Bierregaard, 1995; Bruna and Kress, 2002).

We began by haphazardly selecting $39 \mathrm{H}$. acuminata individuals along the network of trails bisecting Reserve \#1501. We then demarcated a 10x10 m plot around each plant, with the selected plant in the plot's center. These focal plants were randomly assigned to one of three floral neighborhood treatments: one flowering plant/plot, three flowering plants/plot, or five flowering plants/plot. When the natural density of flowering plants within the plot was

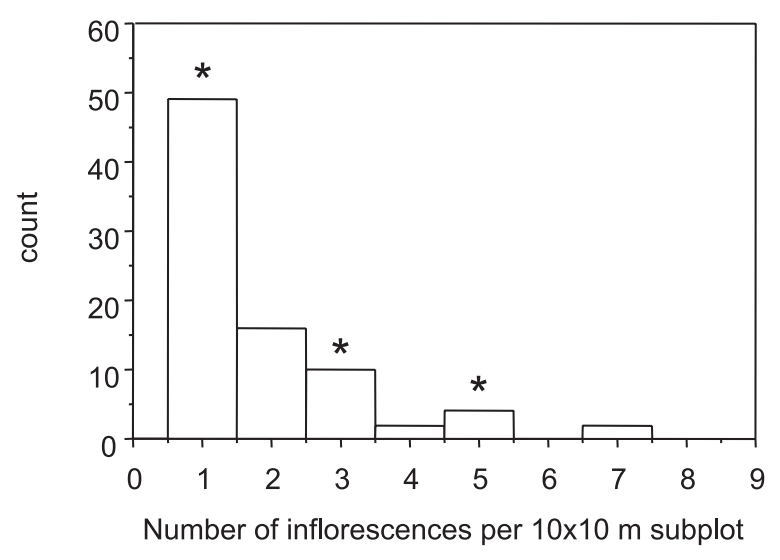

Figure 1 - Number of 10x10 m demographic subplots in which a given number of flowering plants was counted. Asterisks indicate flowering plant densities used in the experiment. These data are from the 1999 flowering season (see Bruna and Kress, 2002 for details). 


\section{ACTA \\ AMAZONICA}

Heliconia acuminata REPRODUCTIVE SUCCESS IS INDEPENDENT OF LOCAL FLORAL DENSITY higher than the treatment to which the plant was assigned, we reduced the number of flowering plants by pruning the other inflorescences. When the density of flowering plants was lower than the treatment density, we increased the number of flowering plants by transplanting reproductive individuals into the plot. These plants, whose inflorescences had yet to open, were planted in a randomly selected location within the plot. Preliminary studies by one of us (EMB) indicated the growth, survivorship, and flowering of transplanted plants were similar to that of naturally occurring ones. All transplants and observations were conducted from January-June, 1998.

There were 13 replicates of each floral neighborhood treatment. For each focal plant in each replicate, we measured the following three surrogates of plant fitness: (1) fruit set (the proportion of flowers developing into mature fruits) (2) total seed production, and (3) the number of seeds produced per fruit. Since the assumptions of parametric statistics could not be met, for each surrogate we compared the median value in each floral neighborhood treatment using Kruskal-Wallis tests. The $P$-value for significance was reduced based on a Bonferroni correction for multiple tests $(P$ for significance $=0.05 / 3=0.017)$, as the three response variables are all highly correlated (results not shown).

To determine if pollinators visited high-density treatments more frequently, we conducted observations of the focal plants in seven ( 1 flowering plant), seven (3 flowering plants), and four ( 5 flowering plants) of the experimental plots. Observations began when flowers opened (6:00-7:00 am), and continued uninterrupted until noon. Preliminary observations indicated hummingbird visits were extremely rare after midday. One day of observation was conducted in each plot. The visitation rates (number of visits/hour) in the different density treatments were again compared using Kruskal-Wallis tests.

\section{RESULTS}

The proportion of $H$. acuminata flowers developing into mature fruits was variable, with an overall mean value of $0.30 \pm 0.24 \mathrm{SD}$ (range $=0-0.88$ ). The total number of seeds produced per plant was also low and variable, with an overall mean of only 4.74 $\pm 6.10 \mathrm{SD}$ (range $0-27$ ). On average each flower contributed only $0.27 \pm 0.33$ SD seeds (range $=0-1$, Table 1). There were no significant differences between focal plants from the different density treatments for any of the surrogates of fitness measured (fruit set: $\mathrm{H}=0.081, P=0.96$; total seed production: $\mathrm{H}=1.349, P=0.51$; seeds/fruit:
$\mathrm{H}=2.15, P=0.34)$.

Over the course of 91.7 hours of observation we recorded only 21 visits to focal plants. Plants received 00.7 visits per hour, with the total number of visits over the course of the observation periods averaging $1.17 \pm 0.26 \mathrm{SE}$ (range $=0-4$ ). Once again, there was no significant difference between focal plants in the different density treatments (median visitation rate for all treatments $=0.182$ visits/hour, $\mathrm{H}=0.99, P=0.63)$.

\section{DISCUSSION}

While previous studies have shown that the local abundance of flowering conspecifics can strongly influence reproduction in tropical plants (Feinsinger et al., 1991), our results suggest $H$. acuminata fecundity is independent of floral neighborhood. Observations of reproductive plants suggest this could be due to $P$. superciliosus and $P$. bourcieri failing to find flowering $H$. acuminata scattered throughout the forest. For example the plant in our study receiving the greatest total number of visits was probed only 4 times during a 6 hour observation period, and 5 of 18 flowers observed (27.7\%) were not visited at all. However, evidence from other studies suggests this is probably not the case. Hermit hummingbirds, which forage by repeatedly visiting the same plants in a set pattern over the course of several hours or days (i.e, traplining), have been shown to have excellent spatial memory (Sutherland and Gass, 1995), as well as the ability to forage over great distances and in a variety of different habitat types (Stouffer and Bierregaard, 1995, 1996). Instead, the range of flowering plant densities observed in demographic plots may simply be below the threshold at which neighborhood effects would influence hummingbird behavior (Fig. 2).

While high $H$. acuminata density could still increase individual reproductive success, it may only be possible at densities that are rarely observed in nature. Given that during the dry season Heliconia acuminata is the most abundant flowering plant in the understory of the BDFFP reserves, the floral neighborhoods of other species are probably also below the thresholds at which neighborhood effects are important. We therefore argue the absence of neighborhood effects may be a general phenomenon in central Amazonian forests, though additional experiments with other plant-pollinator systems are needed to determine the extent to which this hypothesis is supported.

It is worth noting that while limited visits by pollinators are almost certainly contributing to the low fruit and seed

Table 1 - Values for fitness surrogates measured in focal Heliconia acuminata individuals

\begin{tabular}{lccc}
\hline \hline Density Treatment & Fruit Set(Mean \pm SD) & Total Seed Set (Mean \pm SD) & Seeds/Flower $($ Mean \pm SD) \\
\hline 1 Flowering Plant & $0.30 \pm 0.24$ & $4.08 \pm 3.86$ & $0.25 \pm 0.29$ \\
\hline 3 Flowering Plants & $0.28 \pm 0.24$ & $3.46 \pm 4.82$ & $0.16 \pm 0.23$ \\
5 Flowering Plants & $0.31 \pm 0.21$ & $6.69 \pm 8.56$ & $0.40 \pm 0.43$ \\
\hline \hline
\end{tabular}




\section{ACTA AMAZONICA}

Heliconia acuminata REPRODUCTIVE SUCCESS

IS INDEPENDENT OF LOCAL FLORAL DENSITY sets we observed, other factors could also be partially responsible. Nectar, flowers, and fruits are energetically costly to produce (Bloom et al., 1985), therefore low fruit and seed production could also result from resource limitation (Bloom et al., 1985; Campbell and Halama, 1993; Corbet, 1998). The soils in our study sites, which are typical of those in central Amazonia, have very low levels of phosphorous, nitrogen, and potassium (Laurance et al., 1999; Bruna et al., 2002). A number of studies have demonstrated that the experimental addition of soil nutrients can increase flowering and fruiting success (Montalvo and Ackerman, 1987; Zimmerman and Aide, 1989). While to our knowledge no such studies have been carried out in central Amazonia, there is no reason to expect the results would be otherwise. The low fecundity of $H$. acuminata could also be due to the selective abortion of particular paternal genotypes. This can occur in response to limited resource levels or pollen donors, and can operate at both the individual-seed and whole-fruit levels (Lee and Bazzaz, 1982). Finally, flowers could be serving primarily as pollen donors, increasing the fitness of plants through male rather than female sexual function (Stanton, 1994).

The results of this study suggest the fecundity of Heliconia acuminata central Amazonian plants may be independent of floral neighborhood, at least over the range of plant densities observed in nature. However careful experiments, in which resource levels are experimentally elevated in concert with hand pollinations, could help resolve the extent to which pollinator and resource

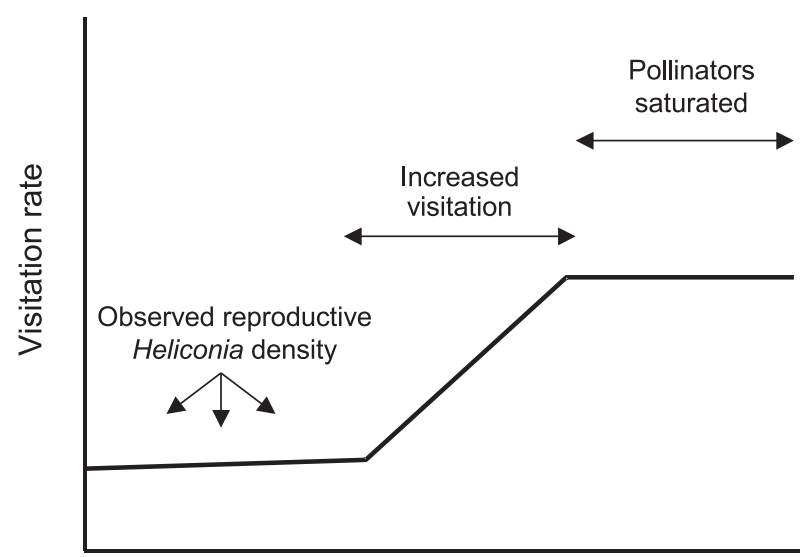

Local density of flowering plants

(floral neighbourhood)

Figure 2 - Hypothetical pattern by which the increasing local density of flowering plants influences local reproductive success. Below a certain threshold density floral neighborhoods are too small to attract increased numbers of pollinators or result in increased visits from resident pollinators At some threshold value visitation rate begins to increase with increase flowering plant density. Eventually, however, the pollinator population becomes saturated and visitation rate no longer increases with neighborhood size. limitation interact to limit the reproductive success of $H$ acuminata and other central Amazonian plants.

\section{ACKNOWLEDGEMENTS}

We would like to thank the staff at the Biological Dynamics of Forest Fragments Project for logistical support and the Manaus Free Trade Zone Authority (SUFRAMA) for permission to conduct the research. The National Science Foundation, the Smithsonian Institution, Manomet Observatory (The Kathleen S. Anderson Award), and the Wilson Ornithological Society (The Paul A. Stewert Award) provided financial support. This is publication number 421 in the BDFFP technical series and Article R-09795 of the Florida Agricultural Experiment Station Journal Series.

\section{LITERATURE CITED}

Ackerman, J. D. 1989. Limitations to sexual reproduction in Encyclia krugii (Orchidaceae). Systematic Botany, 14: 101109.

Agren, J. 1996. Population size, pollinator limitation, and seed set in the self-incompatible herb Lythrum salicaria. Ecology, 77: 1779-1790.

Berry, F.; Kress, W. J. 1991. Heliconia: an identification guide. Smithsonian Institution Press, Washington D.C., USA. 334p.

Bloom, A. J.; Chapin, F. S., III; Mooney, H. A. 1985. Resource limitation in plants: an economic analogy. Annual Review of Ecology and Systematics, 16: 363-392.

Bruna, E. M. 2002. Effects of forest fragmentation on Heliconia acuminata seedling recruitment in central Amazonia. Oecologia, 132: 235-243.

Bruna, E. M.; Kress, W. J. 2002. Habitat fragmentation and the demographic structure of an Amazonian understory herb (Heliconia acuminata). Conservation Biology, 16: 1256-1266.

Bruna, E. M.; Nardy, O.; Strauss, S. Y.; Harrison, S. P. 2002. Experimental assessment of Heliconia acuminata growth in a fragmented Amazonian landscape. Journal of Ecology, 90: 639-649.

Burd, M. 1994. Bateman's principle and plant reproduction: The role of pollen limitation in fruit and seed set. Botanical Review, 60: 83-139.

Calvo, R. N.; Horvitz, C. C. 1990. Pollinator limitation, cost of reproduction, and fitness in plants: A transition-matrix demographic approach. American Naturalist, 136: 499-516.

Campbell, D. R.; Halama, K. J. 1993. Resource and pollen limitations to lifetime seed production in a natural plant population. Ecology, 74: 1043-1051.

Corbet, S. A. 1998. Fruit and seed production in relation to pollination and resources in bluebell, Hyacintboides nonscripta. Oecologia, 114: 349-360.

Feinsinger, P.; Murray, K. G.; Kinsman, S.; Busby, W. H. 1986. Floral neighborhood and pollination success in four hummingbirdpollinated cloud forest plant species. Ecology, 67: 449-464. 


\section{ACTA AMAZONICA}

Heliconia acuminata REPRODUCTIVE SUCCESS IS INDEPENDENT OF LOCAL FLORAL DENSITY
Feinsinger, P.; Tiebout, H. M., III; Young, B. E. 1991. Do tropical bird-pollinated plants exhibit density-dependent interactions? Field experiments. Ecology, 72: 1953-1963.

Gentry, A. H.; Emmons, L. H. 1987. Geographical variation in fertility, phenology and composition of the understory of neotropical forests. Biotropica, 19: 216-217.

Harper, J. L. 1977. Population biology of plants. Academic Press, New York, NY, USA. 892p.

Horvitz, C. C.; Schemske, D. W. 1988. A test of the pollinator limitation hypothesis for a neotropical herb. Ecology, 69: 200206.

Jennersten, O.; Nilsson, S. G. 1993. Insect flower visitation frequency and seed production in relation to patch size of Viscaria vulgaris (Caryophyllaceae). Oikos, 68: 283-292.

Kress, W. J. 1983. Self-incompatibility systems in Central American Heliconia. Evolution, 37: 735-744.

Kunin, W. E. 1993. Sex and the single mustard: population density and pollinator behavior effects on seed set. Ecology, 74: 21452160.

Kunin, W. E. 1997. Population size and density effects in pollination: pollinator foraging and plant reproductive success in experimental arrays of Brassica kaber. Journal of Ecology, 85: 225-234.

Laurance, W. F.; Fearnside, P. M.; Laurance, S. G.; Delamonica, P.; Lovejoy, T. E.; Rankin-de Merona, J. M.; Chambers, J. Q.; Gascon, C. 1999. Relationship between soils and Amazon forest biomass: A landscape-scale study. Forest Ecology and Management, 118: 127-138.

Lee, T. D.; Bazzaz, F. A. 1982. Regulation of fruit set and seed production in an annual legume, Cassia fasciculata. Ecology, 63: 1363-1373.
Montalvo, A. M.; Ackerman, M. D. 1987. Limitations to fruit production in Ionopsis utricularioides (Orchidaceae). Biotropica, 19: 24-31.

Stanton, M. L. 1994. Male-male competition during pollination in plant populations. American Naturalist, 144: S40-S68.

Stouffer, P. C.; Bierregaard, R. O. 1995. Effects of forest fragmentation on understory hummingbirds in Amazonian Brazil. Conservation Biology, 9: 1085-1094.

Stouffer, P. C.; Bierregaard, R. O. 1996. Forest fragmentation and seasonal patterns of hummingbird abundance in Amazonian Brazil. Ararajuba, 4: 9-14.

Sutherland, G. D.; Gass, C. L. 1995. Learning and remembering of spatial patterns by hummingbirds. Animal Behaviour, 50: 1273-1286.

Zimmerman, J. K.; Aide, T. M. 1989. Patterns of fruit production in a Neotropical orchid: Pollinator vs. resource limitation. American Journal of Botany, 76: 67-73. 